\title{
The Probability of a Linkage between Marker and a Locus in Livestock and Laboratory Animals
}

\author{
Akira NISHIDA, Kazuyoshi CHIBA, Takayuki KONARI, \\ Hisashi SHINOHARA and Toshihiro YAMAGISHI \\ Faculty of Agriculture, Tohoku University, Aoba-ku Sendai-shi 981
}

(Received June 23, 1995)

\begin{abstract}
The probability of a linkage with assigned tightness between one of the markers and a locus was evaluated in some species of livestock and laboratory animals. The locus was assumed to control a trait. The tightness of the linkage was arbitrarily assignable as the physical distance; $d$, between the nearest marker and a locus in the evaluation. When $d$ was relatively small ; up to $1 \sim 2 \%$ of total autosomal genome size, the probability of a linkage ; $\operatorname{Pr}(D$ $\leqq d$ ), increased rapidly with increasing $d$. The rate of increase in the probability declined with further increment of $d$. The probability was determined almost entirely by the haploid number of autosomal chromosome in the animals considered. If the number of marker; $m$, was an assigned value, e.g. $m=50$, the $\operatorname{Pr}(D \leqq d)$ was higher for animals with smaller number of chromosome and the differences among animals gradually increased with $d$. When $d$ was $5 \%$ of autosomal genome size and $m$ was 50, the linear regression coefficient of the $\operatorname{Pr}(D \leqq d)$ on the haploid number of autosomal chromosome was -.0076 and the simple correlation coefficient between these two was 0.98 . The probability of a linkage at $d$ is $5 \%$ of autosomal genome size increased with increasing $m$ and the differences in the $\operatorname{Pr}(D \leqq d)$ among Chinese hamster $(n=10)$, rat $(n=20)$ and cattle $(n=29)$ maximized at $m$ was 20 . The differences reduced either $m$ was greater or smaller than 20 . In swine, it requires about 500 randomly distributing markers to find a linkage between one of the markers and a locus within 0.25 percent of autosomal genome size distance ; i.e. 5 centi Morgan, with higher probability than 0.9 .
\end{abstract}

Anim. Sci. Technol. (Jpn.) 67 (1):1-6, 1996

Key words : genetic marker, probability of linkage, livestock, laboratory animals, gene mapping

The economical loss caused by some genetic disorders is not negligible in animal husbandry. Since some of the disorders have been estimated to be controlled by rather small number of recessive genes ${ }^{9)}$, it is difficult to remove these genes completely from a population by selection based only on the phenotype. When we confirmed the existence of a locus which control a trait, the mapping of the locus is necessary to realize a marker assisted culling or culling based on DNA test.

Lander and Botstein ${ }^{6)}$ described a method for exploiting the full power of RFLP linkage map by adapting LOD score analysis to estimate the genetic location and phenotypic effect of quantitative trait loci; QTLs. In their simulation study to verify the method for mapping QTLS, they assumed RFLP markers spaced every 20 centi Morgan throughout the genome.

The purpose of the present study is to evaluate the probability of a linkage with assigned tightness between one of the markers and a locus in some species of livestock and laboratory animals. 


\section{NISHIDA, CHIBA, KONARI, SHINOHARA and YAMAGISHI}

\section{Method}

Elston and Lange ${ }^{4)}$ has shown that the detection probability $; \operatorname{Pr}(D \leqq d)$, of an autosomal linkage between a polymorphic marker locus and a targeting locus ; $L$, which control a trait, within a certain physical distance ; $d$, in fraction of total autosomal genome size is given by

$$
\begin{aligned}
\operatorname{Pr}(D \leqq d)= & \sum_{i=1}^{n} \operatorname{Pr}\left(L \text { is on } C_{i}\right) \sum_{k=1}^{m} \operatorname{Pr}[(k \text { markers } \\
& \text { are on } \left.C_{i}\right) * \operatorname{Pr}(D \leqq d \mid L \text { and } k \\
& \text { markers are on } \left.\left.C_{i}\right)\right] \\
= & \sum_{i=1}^{n} c_{i} \sum_{k=1}^{m}\left(\begin{array}{c}
m \\
k
\end{array}\right) c_{i}^{k}\left(1-c_{i}\right)^{m-k} \operatorname{Pr}(D \leqq d \mid \\
& \left.L \text { and } k \text { markers are on } C_{i}\right)
\end{aligned}
$$

where

$n$ : haploid number of autosomal chromosome,

$C_{i}:$ the $i$-th chromosome,

$m$ : total number of marker,

$c_{i}$ : proportional length on the $i$-th chromosome of the total autosomal genome size,

$\left(\begin{array}{c}m \\ k\end{array}\right)$ : the combination of $m$ markers taken $k$ at a time,

$\left(\begin{array}{c}m \\ k\end{array}\right) c_{i}^{k}\left(1-c_{i}\right)^{m-k}$ : probability of binomial distribution,

$\operatorname{Pr}\left(D \leqq d \mid L\right.$ and $k$ merkers are on $\left.C_{i}\right):$ probability of "the locus $L$ is within distance $d$ from the nearest marker" under the condition of " $L$ and $k$ markers are on the $i$-the chromosome".
Using the above equation, the probability of linkage with an assigned tightness were evaluated on domestic animals; i.e. cattle (Bos taurus), goat (Capra hircus), swine (Sus scrofa) and rabbit (Oryctolagus cuniculus); and laboratory animals ; i.e. rat (Ruttus norvegicus), mouse (Mus musculus), Syrian hamster (Mesocricetus auratus) and Chinese hamster (Cricetulus griseus). The relative length of each autosomal chromosome of the animals reported in the references $2,3.5,7.8,10,11,13$ ) were used for the evaluation.

For example, the relative length of autosomal chromosome of swine is given in Table 1.

\section{Results and Discussion}

We should remember at first that Elston and Lange ${ }^{4)}$ made the following simplifying assumption : (1) Each locus is regarded as a point on the chromosome, (2) Any locus can be taken as a random point on the autosomal genome, with negligible errors in the results obtained. In practice, the number of randomly distributing markers have to be transformed into equidistant equivalent number of markers to realize a detection probability of a locus with an assigned minimum accuracy.

The haploid number of autosomal chromosome; $n$, and the range of the relative length of each chromosome are given in Table 2 for the eight species of animals. The simple correlation between $n$ and the range was -0.88 . The

Table 1. The relative length of each autosomal chromosome in swine (Sus scrofa domestica $L$.)

\begin{tabular}{cccccc}
\hline $\begin{array}{c}\text { Chromosome } \\
\text { number }\end{array}$ & $\begin{array}{c}\text { Length } \\
*(\%)\end{array}$ & $\begin{array}{c}\text { Chromosome } \\
\text { number }\end{array}$ & $\begin{array}{c}\text { Length } \\
*(\%)\end{array}$ & $\begin{array}{c}\text { Chromosome } \\
\text { number }\end{array}$ & $\begin{array}{c}\text { Length } \\
*(\%)\end{array}$ \\
\hline 1 & 13.53 & 7 & 5.55 & 13 & 10.29 \\
2 & 5.82 & 8 & 6.04 & 14 & 7.16 \\
3 & 5.03 & 9 & 5.55 & 15 & 5.48 \\
4 & 5.26 & 10 & 3.87 & 16 & 3.80 \\
5 & 4.77 & 11 & 3.47 & 17 & 2.86 \\
6 & 6.60 & 12 & 2.57 & 18 & 2.35 \\
\hline
\end{tabular}

* Measurement from Fig. 20 of Rønne et $a l^{(1)}$. 
Number of Marker to Map a Locus

Table 2. The haploid number of autosomal chromosome; $n$, and the range of relative chromosome length as percent of the total autosomal genome size in eight species of animals

\begin{tabular}{lcclcc}
\hline \multicolumn{1}{c}{ Species } & $n$ & Range (\%) & Species & $n$ & Range (\%) \\
\hline C. hamster & 10 & 18.96 & Rabbit & 21 & 7.66 \\
Swine & 18 & 11.18 & S. hamster & 21. & 5.56 \\
Mouse & 19 & 5.17 & Goat & 29 & 3.98 \\
Rat & 20 & 8.58 & Cattle & 29 & 3.78 \\
\hline
\end{tabular}

C. hamster: Chinese hamster, $\mathrm{S}$. hamster : Syrian hamster

linear regression coefficient of the range on the $n$ was -0.73 . The relative length of each chromosome are visualized in Fig. 1 for the typical five species of animals. The curvilinearity; concaveness upward, of the graph tended to decrease with increasing number of chromosome from 10 of Chinese hamster to 29 of cattle.

The detection probability of an autosomal linkage between one of the markers and a targeting locus ; $\operatorname{Pr}(D \leqq d)$, within distance $d$ in fraction of total autosomal genome size in each species are shown in Fig. 2 when $m$ markers are used. Since the probability $\operatorname{Pr}(D \leqq d)$ is determined almost entirely by the $n$ and the effect of the variance in relative length of each chromosome is small under usual conditions, the graphs for mouse $(n=19)$, rat $(n=20)$ and swine $(n=18)$ are similar with each other. Then, only the graph for swine is given as a representative of them. Further the graphs for rabbit $(n=21)$ and goat $(n=29)$ are also omitted because they are almost the same as the graphs for Syrian hamster $(n=21)$ and cattle $(n=29)$, respectively. The $m$ was assigned as $1,10,20,30$, $50,100,300$ and 500 in each case. In these Figures, the length of abscissas represents the physical fraction of the longest autosomal chromosome of the species. When $d$ was relatively small, up to $1 \sim 2 \%(0.01 \sim 0.02)$ of total autosomal genome size, the $\operatorname{Pr}(D \leqq d)$ increased quickly with increasing $d$, then the rate of increase in the $\operatorname{Pr}(D \leqq d)$ declined with further increment of $d$. This tendency was marked in the case of larger number of marker. The practical validity of genetic markers for gene
Relative length(\%)

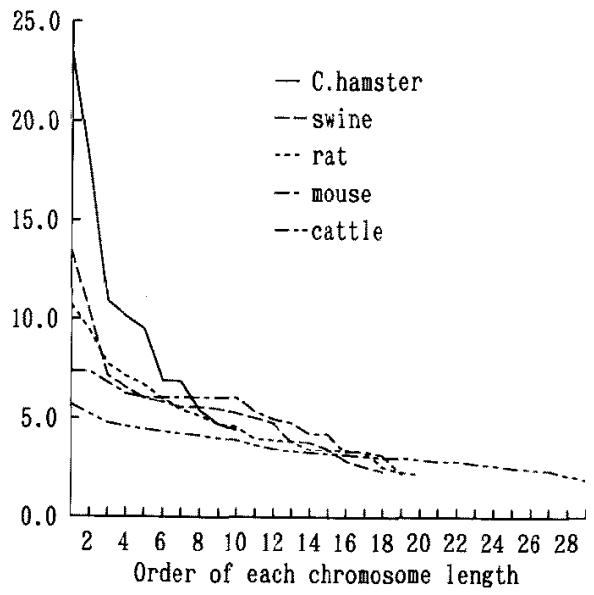

Fig. 1. The relative length of each autosomal chromosome in five species of animals

mapping and for marker assisted selection depends on the recombination fraction with the linked locus. In swine, for instance, it requires about 500 randomly distributing markers to find a linkage between one of the markers and a locus within 0.25 percent of autosomal genome size distance; i.e. 5 centi Morgan ${ }^{1)}$ since the whole length of pig genetic map has been estimated as 20 Morgan, with higher probability than 0.9 . The maps are now available which cover porcine genome with a resolution of at least 20 centi Morgan. This means more than 100 equidistant equivalent markers are already known. Research under international project is now rapidly evolving the map of new markers for higher accuracy and detecting probability of a locus. 
NISHIDA, CHIBA, KONARI, SHINOHARA and YAMAGISHI
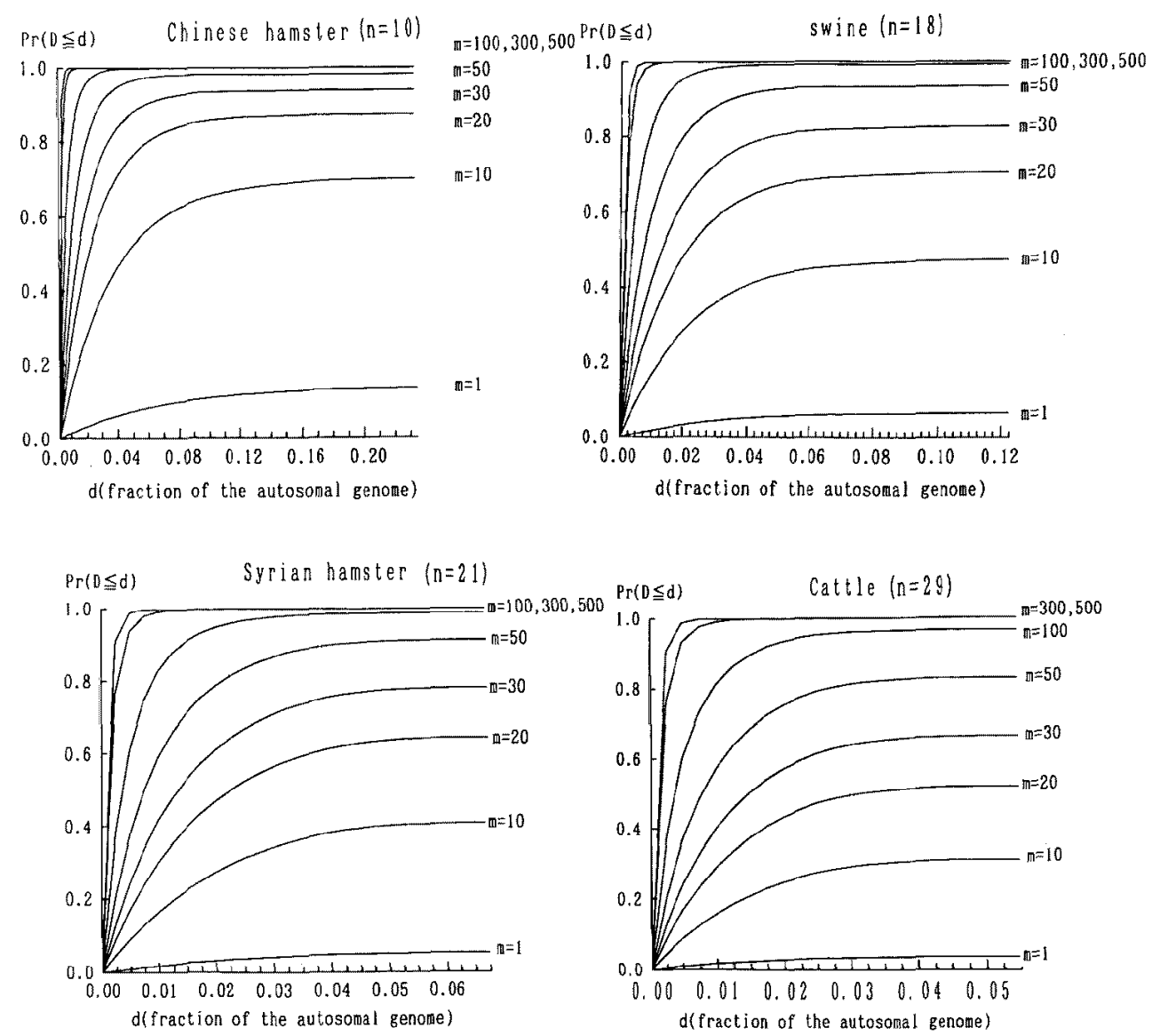

Fig. 2. The detection probability of an autosomal linkage between one of the markers and a locus $; \operatorname{Pr}(D \leqq d)$, within physical distance $d$ in fraction of total autosomal genome size in Chinese hamster, swine, Syrian hamster and cattle

The graphs for mouse and rat were similar to that for swine. The graphs for rabbit and goat were similar to those for Syrian hamster and cattle, respectively. The length of abscissas represents the fraction of the longest autosomal chromosome.

In the case of $m=50$, the differences in the $P r$ $(D \leqq d)$ among animals are shown in Fig. 3. The $\operatorname{Pr}(D \leqq d)$ was higher for animals with smaller number of chromosome and the differences among animals gradually increased with $d$.

Fig. 4 shows the relationship between the $\mathrm{Pr}$ $(D \leqq d)$ and $n$ when $d$ is 0.05 and $m$ is 50 . The linear regression coefficient of the $\operatorname{Pr}(D \leqq d)$ on $n$ was -0.0076 and the simple correlation coefficient between these two was -0.98 .

The $\operatorname{Pr}(D \leqq d)$ increased with increasing $m$ as illustrated in Fig. 5 when $d$ was 0.05 . The differences in the $\operatorname{Pr}(D \leqq d)$ among Chinese hamster, rat and cattle, their haploid number of autosomal chromosome are 10,20 and 29 respectively, maximized when $m$ was 20 . The differences reduced either $m$ was greater or smaller than 20.

Regardless the selection of "positional clon. ing", "candidate gene approach" or "comparative method among species" to map a locus"), or "interval mapping" presented by Lander and Botstein $^{6)}$ to search QTLs, sufficient number of 


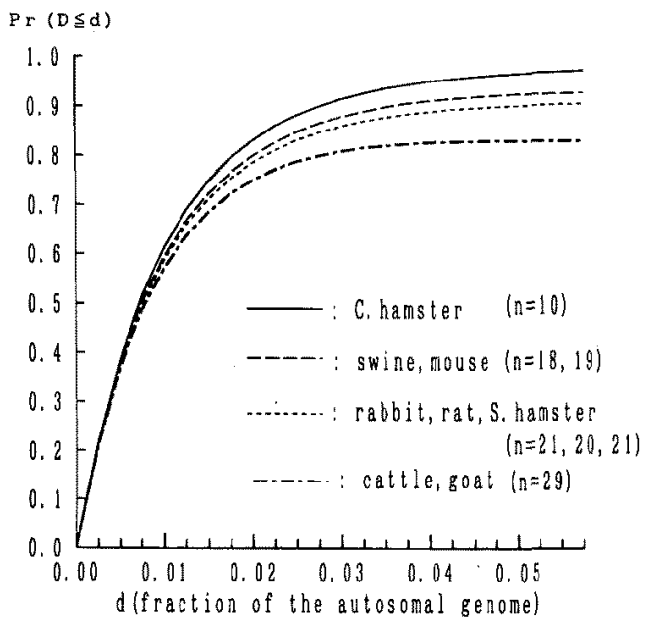

Fig. 3. The differences in detection probability of a linkage; $\operatorname{Pr}(D \leqq d)$, among eight species of animals when 50 markers are used

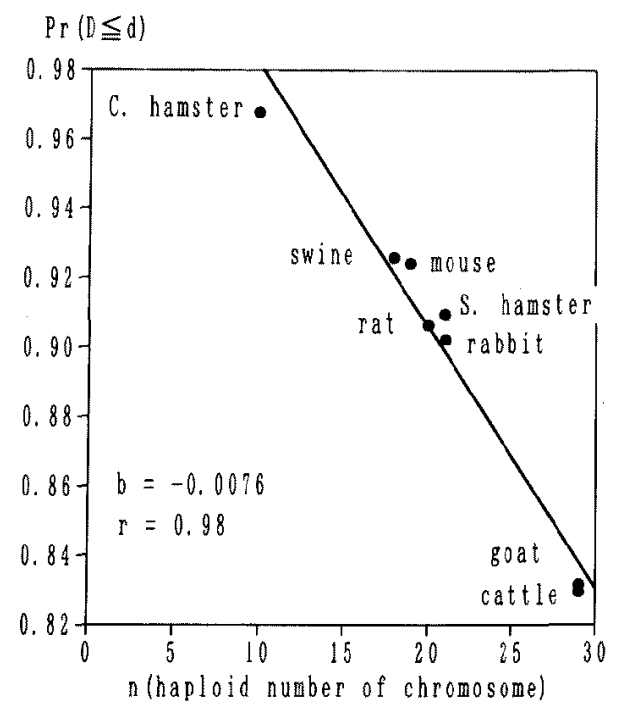

Fig. 4. The relationship between detection probability of a linkage; $\operatorname{Pr}(D \leqq d)$, and the haploid number of autosomal chromosome; $n$, when $d=0.05$ and $m=50$

highly polymorphic genetic markers are necessary ${ }^{12)}$ for further improvement of the efficiency.

The computer program in BASIC is available from the author for the evaluation of detection probability of a linkage using the equation of

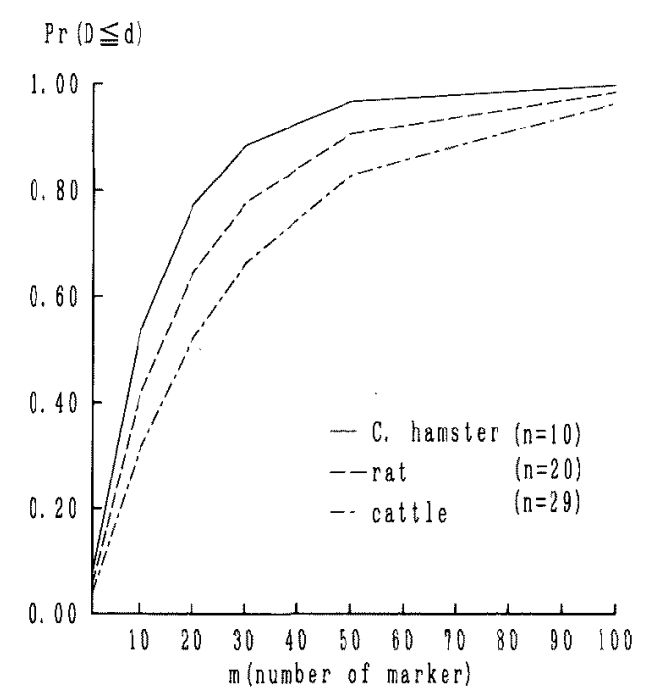

Fig. 5. The relationship between detection probability of a linkage $\operatorname{Pr}(D \leqq d)$, and number of marker used; $m$ for three animals when $d=$ 0.05

Elston and Lange ${ }^{4)}$.

\section{Acknowledgement}

The authors wish to express their sincere appreciation to Dr. Hirofumi Hanada for helpful suggestion on the chromosome length of the animals.

\section{References}

1) Archibald AL, Burt DW, Williams JL. Gene mapping in farm animals and birds : An overview. Proc. 5th World Congress on Genetics Applied to Livestock Production, 21:5-12. 1994.

2) Committee for standardized karyotype of Oryctolagus cuniculus. Standard karyotype of the laboratory rabbit, Oryctolagus cuniculus. Cy togenet. Cell Genet., $31: 240-248.1981$.

3) Committee for standardized karyotype of Rattus norvegicus. Standardized karyotype of the Norway rat, Rattus norvegicus: Cytogenet. Cell Genet., 12 : 199-205. 1973.

4) Elston RC, Lange K. The prior probability of autosomal linkage. Ann. Hum. Genet. Lond., $38: 341-350.1975$.

5) Gustavsson I. Cytogenetics, distribution and phenotypic effects of a translocation in Swed- 


\title{
NISHIDA, CHIBA, KONARI, SHINOHARA and YAMAGISHI
}

ish cattle. Hereditas, $63: 68-169.1969$.

6) Lander ES, Botstein D. Mapping Mendelian factors underlying quantitative traits using RFLP linkage maps. Genetics, $121 ; 185-199$. 1989.

7) Li S, Pathak S, Hsu TC. High resolution Gbanding patterns of Syrian hamster chromosomes. Cytogenet. Cell Genet., $33: 295-302$. 1982.

8) Nesbitt MN. In inbred and genetically defined strains of laboratory animals. Part 1. Mouse and Rat (Altman PL, Katz DD. ed.) 40. Fed. Am. Soc. Exp. Biol, Bethesda. 1979.

9) Ollivier L, Sellier P. Pig genetics : a review. Ann. Génét. Sél. anim., $14: 481-544.1982$.

10) Ray M, Mohandas T. Proposed banding no- menclature for the Chinese hamster chromosomes (Cricetulus griseus). Cytogenet. Cell Genet., 16:83-91. 1976.

11) Rønne M, Stefanova V, Diberadino D, Poulsen $\mathrm{SB}$. The R-banded karyotype of the domestic pig (Sus scrofa domestica L.). Hereditas, 106 : 219-231. 1987.

12) Terwilliger J, Ding $Y$, Ott J. On the relative importance of marker heterozygosity and intermarker distance in gene mapping. Genomics, $13:$ 951-956.1992.

13) Tsuda $S$, Kotani $M$, Shimaoka $T$, Tanaka $K$. Chromosome analysis of the domestic goat using high-resolution chromosome G-banding technique. Jpn. J. Zootech. Sci., $59: 1-11.1988$.

\section{家畜と実験動物における一遺伝子座とマーカーとの連鎖の確率}

\author{
西田 朗・千葉和義・小成隆敬・策原 久・山岸敏宏 \\ 東北大学農学部, 仙台市青葉区 981
}

\begin{abstract}
家畜と実験動物の計 8 品種において，ある道伝子座とマーカー遗伝子座のうちの一つとが，一定の強 さで連鎖している確率を求めた，その遗伝子座は，一つで 1 形質を支配していると仮定した，確率の計 算にあたり，連鎖の強さは，最も近いマーカー加らの物理的距離 $d$ として，任意に指定できる. 距離 $d$ がゲノムサイズの1〜2\%までの範用で，目的とする遺伝子座と一つのマーカーとの連銷が見つかる確 率 $\operatorname{Pr}(D \leqq d)$ は， $d$ の增加とともに急速に高まった. $d$ がこの範同を超えると，一定量の $d$ の增加に対す る確率の上昇量は小さくなった、確率 $\operatorname{Pr}(D \leqq d)$ は，ほとんど完全に常染色体の数 $n$ により決定されて いた．使えるマーカーの数 $m$ が，例えば 50 上一定であれば，nの少ない動物ほど $\operatorname{Pr}(D \leqq d)$ が高く， $d$ が大きくなるにつれてしだいに $\operatorname{Pr}(D \leq d)$ の動物間差は広がった。 $d$ がゲ/ムサイズの $5 \%$ で， $m$ が 50 のとき, $\operatorname{Pr}(D \leqq d)$ のに対する一次回帰係数は一 0.0076 , 両者の間の相関は 0.98 であった. 距離 $d$ がゲ ノムサイズの 5\%となる正確さで遭伝子座とマーカーとの連鎖を見つけられる確率は $m$ の增加ととも に高まり, チャイニーズハムスター $(n=10)$, ラット $(n=20)$, ウシ $(n=29)$ の間の $\operatorname{Pr}(D \leqq d)$ の差は, $m=20$ のときに最大で, $m$ が 20 から遠ざかるにつれて小さくなった，豚のある道伝子座とマーカーの うちの一つが，ゲ/ムサイズの 0.25\%以下の距㒕で連鎖しているのを，0.9より高い雅摔で見つけるに は，約500の無作為伅分布するマーカーが必要であった．䀠の性染色体を除くゲ/ムサイズは，約 20 モ ルガンであると推定されているので，その $0.25 \%$ は，ほぼ5センチモルガンにあたる.
\end{abstract}

日畜会報, $67(l): 1-6,1996$ 